\title{
Second Wave Covid-19: Survey on Attitudes and Acceptance of Vaccines and Psychological Impact of Second Wave
}

\section{Vaishnavi P1, Shebin Sharief2, J. Ramprasath ${ }^{3}$}

'Assistant professor, Department of Management studies, Ayyan Thiruvalluvar College of arts and Science-Coimbatore, India; 'Assistant Professor, Master Business Administration, 1CET, Muvattupuzha, Ernakulum, India; ${ }^{3}$ sssistant professor, Department of Information Technology, Dr. Mahalingam College of Engineering and Technology, India.

\section{ABSTRACT}

Introduction: The second wave of COVID-19 is distressing the majority of the planet. This raised questions about approximately a conceivable second wave of coronavirus infection in 2019. (COVID-19).

Objective: The aim of this overview was to find out the level of vaccine information, demeanors, and acknowledgment, as well as to survey the mental status in connection to the second wave of COVID-19. Further, acceptance of COVID-19 vaccines is analyzed for Indian states by evaluating test inspiration and case death rates. At last, figures and noteworthy inputs are given based on scientific and epidemiological models.

Methodology: Snowball sampling at procedures was utilized to perform the online overview.

Results: The results are compared to the current COVID-19 wide scene; they choose up to urge to the mindfulness arrange, state of intellect against the antibodies, uneasiness, passionate trouble, as the affected individuals are seen as tall compared to the primary wave.

Conclusion: It is especially critical to require care of the population's mental well-being and valuable measures to moderate its badly arranged impacts within the middle of the COVID-19 second wave far-reaching, in spite of the truth that for the patients who are recovered from the COVID-19.

Key Words: COVID-19, Second wave, Vaccines, Attitude, Behavior, Psychological impact

\section{INTRODUCTION}

More than a year after the World Health Organization (WHO) announced COVID-19 a widespread on Walk 11, 2020, the dangerous SARS-CoV-2 infection proceeds to undermine open life around the world. Whereas most lockout standards have been loose, social life remains distant from typical. ${ }^{10,12}$ A few immunizations have as of late been created by Oxford Covishield/Vaxzevria), Bharat Biotech (Covaxin), and others. However, mass-producing and disseminating vaccinations to cover a vast populace remains a difficult challenge. Meanwhile, most countries are also implementing anti-virus measures such as masking, psychological distancing guidelines, partial lockdowns, and shortened shop hours to keep the virus from spreading during the vaccine program.

The second wave is distinctive from the primary wave in September 2020 in two imperative ways: to begin with, the rate of increment in modern cases is altogether higher. The increment from 10,000 to 80,000 modern cases per day from February to April has taken less than 40 days.

To meet the expanding request, state governments over the nation are working to guarantee the accessibility of sufficient healing center beds, both ICU and non-ICU, for COVID administration, as well as extended capacity in COVID Care Centers (CCCs) in both the open and private divisions. ${ }^{1,8,11}$

The second outbreak of COVID-19 contaminations has taken India's healthcare system off balance, with research failures and reports of critical-care bed, oxygen, and healing center shortages, effectively leaving ill patients without medication. The ice-cold quest for healing center beds may be a nationwide occurrence., ${ }^{2,13,14}$ India is now dealing with the outbreak's myriad impacts on accessible health and social mediations, as current vulnerabilities are exacerbated

\section{Corresponding Author:}

Dr. Vaishnavi P, Assistant professor, Department of Management studies, Hindustan College of arts and Science-Coimbatore, India. Email: vaishnavipalanisamy@gmail.com

ISSN: $2231-2196$ (Print)

Received: 20.11 .2021
ISSN: 0975-5241 (Online)

Revised: 16.12 .2021
Accepted: 12.01 .2022 
and new vulnerabilities arise, in addition to the wellbeing impacts of the SARS-COV-2 infection and the COVID-19 disease $^{3,16}$. Casual laborers who work in densely developed, low-resource metropolitan areas have suffered significantly as a result of these changes. Quickened immunization campaigns are basic to the government's endeavors to avoid the spread of COVID-19. With the later increment in episodes, the government's possess objective is to manage 5 million dosages a day to individuals over the age of $45 .{ }^{17,12}$

The COVID-19 widespread has come to a basic point in India. To begin with put, all endeavors must be made to break the transmission chain and decrease the rate of modern diseases whereas causing the slightest harm to the economy and people's employments. At the same time, accelerated vaccines would help within the long-term control of the widespread. The past year has appeared, both inside India and in other nations, that solid political will, combined with health-system status and individual and community behavior alter, can create capably comes about. We trust that great, definitive steps taken presently will spare India from a longmoment wave of COVID-19 diseases and will put measures in put to dodge future waves of COVID-19 diseases. . $^{7,15}$

\section{RESEARCH PROBLEM}

Vaccine hesitancy applies to the postponement or refusal of vaccines due to a lack of vaccine facilities. Factors like ease of use and confidence have an effect. Governments and societies must evaluate existing levels of awareness and ability to access a theoretically secure and reliable COVID-19 vaccine, as well as identify the root causes of vaccine skepticism. ${ }^{6,8}$ As a result, the aim of this Pan-India online survey was to determine how well our people knew about and accepted the latest COVID-19 vaccination program. Since COVID-19 vaccines are recent, there might be some doubt regarding their acceptance; as a result, we performed this research to better understand the situation and enable better use of resources.

It's important to understand as much as possible about the public's desires, reality, demeanors, and attitudes through an irresistible challenging outbreak in the second wave. Such data will help public health authorities and doctors in their attempts to increase connectivity. According to our interpretation, the bulk of research on this episode focuses on differentiating the evaluation of disease transmission and clinical characteristics of infected individuals, genomic characterization of the virus, and public health administration challenges. ${ }^{4,5}$ In either event, no investigative studies have been published on the effect of the COVID-19 second wave on India's general population's mental wellbeing. This study also provides a description of the real psychological condition of citizens in the second wave of COVID-19, which is not discussed in other reports.

\section{OBJECTIVE OF THE STUDY}

1. To analyze the level of acceptance of COVID-19 vaccines among individuals, as well as their attitudes and behavior during the second wave.

2. To investigate the current psychological status of individuals during the second wave.

3. To suggest the measures and coping techniques to improve the psychological health of the individual during the pandemic situation of second

\section{RESEARCH METHODOLOGY}

The current survey research is focused on important information gathered from 780people from various parts of Tamilnadu, India. The data was collected using the snowball sampling survey methodology. Using an online survey, a cross-sectional overview plan was developed to assess the public's acceptance and attitude toward vaccines, as well as their psychological status response during the affliction of COVID-19 second wave. The online summary was initially distributed to friends and understudies, who were then encouraged to spread it to others.

\section{SURVEY DEVELOPMENT}

Socio-statistical factors, data and questions regarding COVID-19 vaccines; cautious COVID-19 preventive measures; the emotional effects of the COVID-19 second wave; and emotional well-being state were all included in the summary.

Age, gender, conjugal position, ability, range of place, and occupation are all included in the socio statistics portion. The survey's information level included specifics regarding COVID-19 vaccines and their approval level variables, which included the level of attitude toward vaccines, in conclusion, the level of fulfillment of COVID-19 second wave wellbeing results, the drift of unused cases and moving, and potential COVID-19 contamination care during the second wave. Respondents were required to show where their data came from. A self-administered survey that has been adopted by the Tamilnadu community for assessing the degree of mental effect after the presentation of a public health emergent. In the second wave, people's pain, nervousness, fatigue, and anxiety is used to measure their mental wellbeing.

\section{RESEARCH LIMITATIONS}

The study's most significant limitation is the participants' self-report. As a consequence, there's a chance the reports may be skewed. The study was conducted virtually over the internet, giving researchers access to people who use 
social media. As a consequence, they don't worry about it right away, and they don't come up with a clear finding to back up a desire for a concentrated public health activity. A select number of peers was oversampled, which culminated in choice prejudice. Another stumbling block is that self-reported levels of emotional impact, uneasiness, depression, and stretch cannot be updated on a regular basis for a mental health expert's evaluation. In terms of satisfaction with the health information received and precautionary measures, respondents could have shown socially unfavorable answers.

\section{DATA ANALYSIS AND INTREPRETATION}

Based on our survey it was found that the utmost respondents (55.8\%) contributed towards this research are females and under the age group of 30-40 years (37.5). Major contributions to this study are from married (60.6\%) respondents and most of the samples have post graduate (63.5\%) educational qualification. People residing in village (47.1\%) have contributed much to our study and among the respondents, majority are private employees $(60.6 \%)$. This constitutes the overall demographic analysis of the samples of this research.

\section{AWARENESS, ATTITUDE AND BEHAVIOUR OF PEOPLE TOWARDS VACCINATION}

From Table 1 based on the awareness level and attitude of the respondents, most of them(50\%) gets a daily media exposure of less than 1 hour on COVID-19 related information and they strongly agreed $(58.7 \%)$ that they have awareness about vaccine and its importance. Social me$\operatorname{dia}(45.5 \%)$ gives the major source of awareness about the vaccine to the people. About (54.8\%) of the respondents have no hesitancy to the vaccine and for the rest reason for the hesitancy was no response $(53.8 \%)$. In the same time majority $(60.6 \%)$ of the respondents feels the importance of vaccination. Based on the study majority $(79.8 \%)$ of the respondents are not vaccinated. It is evident from the research that the most of the people (78.6\%) opined that safety measures and medicines are not prescribed by hospitals after vaccination. Most of the respondents (51\%) have positive feeling after the vaccination. Based on the study it is evident that majority (55.8\%) of the respondents have no doubt on the vaccine safety and its efficacy. Fig 1 shows that about $(59.9 \%)$ of the respondent opined that demands of vaccines are the barrier they faced in vaccination. Table 2 shows that fear of going in crowd to vaccinate is the major reason for vaccine hesitancy.

\section{PSYCHOLOGICAL STATUS OF PEOPLE DUR- ING INFECTED AND COVID-19 RECOVERED}

Based on the inferential Table 3majority of our respondent (91.3\%) are COVID-19 negative. About (65.4\%) of the respondent family members are also tested negative. It shows that $(91.3 \%)$ of respondents are not tested COVID-19 positive and about (65.4\%) of respondents have their family or friends not affected with COVID-19. Most of the respondents (90.4\%) have not admitted in the ICU for treatment. Most people opined that they face no sleep problem post recovery period but they faced fear or anxiety problem $(71.2 \%)$ during the treatment. Fear on family safety was felt by at most (94.2\%) the entire respondent. Major portion of the unit (66.7\%) felt lonely and depressed during the treatment and it was an equalizer (50-50\%) in the respondent's opinion towards their experience about change in sleeping and eating pattern. Need for psychological support after recovering from COVID-19 is almost half of the people told that they require the support.

\section{PSYCHOLOGICAL STATUS OF PEOPLE IN SEC- OND WAVE OF COVID-19}

Based on the descriptive analysis of the Table 4shows that among the major concern of fear/ anxiety during second wave, fear of increase in death $(45.2 \%)$ was found to be the major concern of the respondent. Most of the respondent (53.5\%) feels adaptable in the second wave lock down compared to the first lock down. Based on the majority $(66.3 \%)$ of the respondent faced mood swings / change in behavior after returning from treatment. Loss of income (45.2\%) was the main impact on the respondent's life with the prevailing situation of COVID-19 pandemic. Fig 3 shows that respondent strongly agreed $(66.3 \%)$ by the people that they fear much about the second wave compared to first. It is evident from the research that most people (57\%) needs psychological support during the lock down of the second wave and Fig 2 also shows after the recovery (46\%) from COVID-19.

\section{Socio-demographic and Attitude and behaviour of people towards vaccine}

$\mathrm{H}_{1}$ : There is a significant relationship between the age and attitude towards vaccine

\begin{tabular}{lccc} 
Chi-Square Tests & Value & df & $\begin{array}{c}\text { Asymp. Sig. } \\
\text { (2-sided) }\end{array}$ \\
Pearson Chi-Square & $47.367^{\mathrm{a}}$ & 12 & .000 \\
Likelihood Ratio & 25.240 & 12 & .014 \\
Linear-by-Linear Association & .378 & 1 & .539 \\
N of Valid Cases & 104 & & \\
\hline
\end{tabular}

a. 14 cells $(70.0 \%)$ have expected count less than 5 . The minimum expected count is .02. 
Interpretation: Since the value of $\mathrm{P}<0.05$, we reject the null hypothesis. So there exists a significant relationship between the age and attitude towards vaccine

$\mathrm{H}_{2}$ : There is a significant relationship awareness on vaccine safety and vaccine hesitancy

\begin{tabular}{|c|c|c|c|c|c|}
\hline \multicolumn{6}{|c|}{ Chi-Square Tests } \\
\hline & Value & df & $\begin{array}{l}\text { Asymp. } \\
\text { Sig. } \\
\text { (2-sided) }\end{array}$ & $\begin{array}{l}\text { Exact Sig. } \\
\text { (2-sided) }\end{array}$ & $\begin{array}{c}\text { Exact } \\
\text { Sig. } \\
\text { (1-sided) }\end{array}$ \\
\hline $\begin{array}{l}\text { Pearson Chi- } \\
\text { Square }\end{array}$ & $10.612^{\mathrm{a}}$ & 1 & .001 & & \\
\hline $\begin{array}{l}\text { Continuity Cor- } \\
\text { rection }^{b}\end{array}$ & $9 \cdot 359$ & 1 & .002 & & \\
\hline $\begin{array}{l}\text { Likelihood } \\
\text { Ratio }\end{array}$ & 10.761 & 1 & .001 & & \\
\hline $\begin{array}{l}\text { Fisher's Exact } \\
\text { Test }\end{array}$ & & & & .001 & .001 \\
\hline $\begin{array}{l}\text { Linear-by-Line- } \\
\text { ar Association }\end{array}$ & 10.510 & 1 & .001 & & \\
\hline $\begin{array}{l}\mathrm{N} \text { of Valid } \\
\text { Cases }\end{array}$ & 104 & & & & \\
\hline
\end{tabular}

a. o cells $(0.0 \%)$ have expected count less than 5 . The minimum expected count is 20.79 .

Interpretation: Since the value of $\mathrm{P}<0.05$, we reject the null hypothesis. So there exists a significant relationship between the awareness on vaccine safety and vaccine hesitancy

\section{Overall Interpretation}

Based on the above table it's clear that vaccination barriers exist among India and based on the barriers, spending more time in the vaccination centre acts as a major barrier among people to vaccinate, next travelling long disaster to vaccinate acts as a next main barrier among people, and demand of vaccines is also considered a barrier which is ranked in third position.

\begin{tabular}{|c|c|c|c|c|c|c|}
\hline & & $\begin{array}{l}\text { sleep problem } \\
\text { after recovery }\end{array}$ & $\begin{array}{l}\text { Changeine- } \\
\text { atnsleeppat- } \\
\text { tern }\end{array}$ & $\begin{array}{c}\text { anxiety } \\
\text { about health }\end{array}$ & $\begin{array}{c}\text { sleep- } \\
\text { prblminsec- } \\
\text { ondwave }\end{array}$ & $\begin{array}{l}\text { Nervousab- } \\
\text { outsituation }\end{array}$ \\
\hline \multirow{3}{*}{$\begin{array}{l}\text { Anxiety about } \\
\text { health }\end{array}$} & Pearson Correlation & .192 & $.404^{* *}$ & 1 & $.420^{* *}$ & .244 \\
\hline & Sig. (2-tailed) & .156 & .002 & & .001 & .069 \\
\hline & $\mathrm{N}$ & 56 & 56 & 56 & 56 & 56 \\
\hline \multirow{3}{*}{$\begin{array}{l}\text { Sleep problem in } \\
\text { second wave }\end{array}$} & Pearson Correlation & .025 & $.410^{* *}$ & $.420^{* *}$ & 1 & $.282^{*}$ \\
\hline & Sig. (2-tailed) & .853 & .002 & .001 & & .035 \\
\hline & $\mathrm{N}$ & 56 & 56 & 56 & 56 & 56 \\
\hline
\end{tabular}

\begin{tabular}{|c|c|c|}
\hline Factors & $\begin{array}{l}\text { Chi-square } \\
\text { value }\end{array}$ & Interpretations \\
\hline $\begin{array}{l}\text { Gender Vs. Vaccine } \\
\text { hesitancy }\end{array}$ & 0.203 & $\begin{array}{l}\text { Significant relation } \\
\text { between gender and } \\
\text { vaccine hesitancy }\end{array}$ \\
\hline $\begin{array}{l}\text { Area Vs. Mode of } \\
\text { awareness }\end{array}$ & 0.00 & $\begin{array}{l}\text { Significant relation } \\
\text { between area and } \\
\text { mode of vaccine } \\
\text { awareness }\end{array}$ \\
\hline $\begin{array}{l}\text { Awareness of vaccine } \\
\text { Vs. Vaccine hesitancy }\end{array}$ & 0.00 & $\begin{array}{l}\text { Significant relation } \\
\text { between awareness } \\
\text { of vaccine and vaccine } \\
\text { hesitancy }\end{array}$ \\
\hline $\begin{array}{l}\text { Vaccine safety doubts } \\
\text { Vs. Vaccine hesitancy }\end{array}$ & 0.001 & $\begin{array}{l}\text { Significant relation } \\
\text { between doubts on } \\
\text { vaccine safety and } \\
\text { hesitancy on vaccines }\end{array}$ \\
\hline $\begin{array}{l}\text { Awareness of vaccine } \\
\text { Vs. Fear of second } \\
\text { wave }\end{array}$ & 0.003 & $\begin{array}{l}\text { Significant relation } \\
\text { between awareness } \\
\text { level of vaccine and } \\
\text { level of fear on second } \\
\text { wave }\end{array}$ \\
\hline $\begin{array}{l}\text { Fear of second wave } \\
\text { Vs. Change in sleep } \\
\text { pattern }\end{array}$ & 0.040 & $\begin{array}{l}\text { Significant relation } \\
\text { between change in } \\
\text { sleep pattern and fear } \\
\text { of second wave }\end{array}$ \\
\hline
\end{tabular}

\begin{tabular}{|c|c|c|}
\hline \multirow{3}{*}{ Second wave fear } & Pearson Correlation & $.317^{* *}$ \\
\hline & Sig. (2-tailed) & .000 \\
\hline & $\mathrm{N}$ & 510 \\
\hline
\end{tabular}

\section{Interpretation:}

From the above Table, it's understood that correlation is significant at the 0.00 level (2-tailed). It's evident that there is positive correlation between awareness of vaccines and level of fear during second wave. 


\section{SUMMARY OF FINDINGS}

In the statistical analysis, the maximum of the people $(55.8 \%)$ contributed towards this research are females and under the age group of 30-40 years (37.5). Major contributions to this study are from married $(60.6 \%)$ respondents and most of the samples have post graduate (63.5\%) educational qualification. People residing in village $(47.1 \%)$ have contributed much to our study and among the respondents, majority are private employees $(60.6 \%)$. $(60.6 \%)$ of the respondents feels the importance of vaccination. Based on the study majority (79.8\%) of the respondents are not vaccinated. It is evident from the research that the most of the people $(78.6 \%)$ opined that safety measures and medicines are not prescribed by hospitals after vaccination. Most of the respondents (51\%) have positive feeling after the vaccination. Based on the study it is evident that majority $(55.8 \%)$ of the respondents have no doubt on the vaccine safety and its efficacy. About (59.9\%) of the respondent opined that demands of vaccines are the barrier they faced in vaccination. Most people opined that they face no sleep problem post-recovery period but they faced fear or anxiety problem $(71.2 \%)$ during the treatment. Fear on family safety was felt by at most $(94.2 \%)$ the entire respondent. Major portion of the unit $(66.7 \%)$ felt lonely and depressed during the treatment and it was an equalizer (50-50\%) in the respondent's opinion towards their experience about change in sleeping and eating pattern. Need for psychological support after recovering from COVID-19 is almost half of the people told that they require the support. (53.5\%) feels adaptable in the second wave lock down compared to the first lock down. Table 4 and Table 5 shows most of the people $(60.6 \%)$ stay at their home and don't go outside at all during second wave. It was strongly agreed $(52.9 \%)$ by majority of the sample unit that they faced anxiety about health during the second wave but they felt no sleep problems $(60.6 \%)$ faced during second wave. In the same time majority of the people $(63.5 \%)$ were feeling nervous and stress $(70.2 \%)$ during the second wave of COVID-19. It was strongly agreed $(66.3 \%)$ by the people that they fear much about the second wave compared to first. It is evident from the research that most people (57\%) needs psychological support during the lock down of the second wave and also after the recovery (46\%) from COVID- 19. There is positive relation between the awareness and vaccine hesitancy. There is a positive relation between vaccines importance and anxiety level in the second wave.

\section{DISCUSSION}

According to the results, the majority of the participants are conscious of the present pandemic situation in India as well as vaccinations. Additionally, it seems that the majority of the participants regard vaccine demand as a significant ob- stacle that the Indian government should strongly consider. Some of them have had questions about the vaccine and its efficacy, which could be answered by experts by calling any toll-free number, raising vaccine knowledge and value. 71 percent of respondents rated the episode's emotional impact as direct and fearful during treatment; 51 percent of respondents cited significant depression side effects; 46 percent cited high fear and intense stress levels, as well as the desire for psychiatric help long after they recovered. Health professionals should take this into consideration, because they should be able to identify high-risk individuals dependent on sociodemographic evidence in order to include early mental therapies. Since younger people are more receptive to smart phone apps, healthcare providers can recommend providing web or smart phone-based psychoeducation and mental mediations to patients to reduce the post-recovery psychological impact. The major effect of the current covid pandemic on the respondents' lives was a loss of jobs. As people thought about the second wave, they were more anxious and sad than when they thought about the first wave. According to the study, the majority of patients need psychiatric assistance during the second wave lockdown, and health care providers should take this into account. To - the impact of rumors, the government and health experts must provide detailed health details during the outbreak. The precautionary steps taken to prevent the dissemination of COVID-19 could have preventive psychological effects in the early stages of the outbreak.

\section{CONCLUSION}

During the COVID-19 episode's second level. As the affected individuals are seen as a minority and isolated from the majority of the population, the outcomes are related to the existing COVID-19 widespread; they include increased mindfulness, anxiety, uneasiness, and passionate difficulty. A lower mental impact of the flare-up, vaccination supply and understanding, and lower levels of stretch, uneasiness, and suffering were all linked to specific up-to-date and exact health details and some cautious interventions. The mediation measures used by various health experts and government bodies in combating vaccination doubts and demand for vaccination may help in removing the danger during the time of vulnerability; however, multivariate analyses done on previous flare-ups seem to have long-term cognitive and mental wellbeing impacts on the populace. During the COVID-19 second wave, it is important to prioritize the public's emotional health and take constructive measures to mitigate its negative consequences.

\section{ACKNOWLEDGEMENT}

The authors express their sincerest gratitude and warm appreciation to the respondents who participated in this study. 
Authors acknowledge the immense help received from the scholars whose articles are cited and included in references of this manuscript. The authors are also grateful to authors / editors / publishers of all those articles, journals and books from where the literature for this article has been reviewed and discussed.

Source of funding: There was no source of funding.

Conflict of Interest: There is no conflict of interest

Authors' Contribution: Concept and design of the work Vaishnavi P, J. Ramprasath

Data collection - Shebin sharief and J. Ramprasath

Data analysis and interpretation- Vaishnavi. P and Shebin sharief

Drafting the article- Vaishnavi $\mathrm{P}$

Revision and final drafting - Vaishnavi. P, J. Ramprasath and Shebin sharief

\section{REFERNCES}

1. Bao Y, Sun Y, Meng S, Shi J, Lu L. 2019-nCoV epidemic: address mental health care to empower society. The Lancet. 2020;395(10224): e37-e38.

2. Chodkiewicz J, Miniszewska J, Krajewska E, Biliński P. Mental Health during the Second Wave of the COVID-19 Pandemic-Polish Studies. Int. J. Environ. Res. Public Health 2021;18(7):3423.

3. Balkhy HH, Abolfotouh MA, Al-Hathlool RH, Al-Jumah MA. Awareness, attitudes, and practices related to the swine influenza pandemic among the Saudi public. BMC Infectious Diseases. 2010;10(1).

4. Samal J. Impact of COVID-19 infodemic on psychological wellbeing and vaccine hesitancy. Egypt J Bronchol. 2021;15(1).

5. Iftimie S, López-Azcona AF, Vallverdú I, Hernández-Flix S, De Febrer G, Parra S. First and second waves of coronavirus dis- ease-19: A comparative study in hospitalized patients in Reus, Spain. PLOS ONE. 2021;16(3)

6. Janmejaya S. Impact of COVID-19 infodemic on psychological wellbeing and vaccine hesitancy (2021), Egypt J Bronchol(2021) 15:14

7. Saiful I. Knowledge, attitudes and perceptions towards COVID-19 vaccinations: a cross-sectional community survey in Bangladesh, BMC Public health,

8. Nishiura H, Jung S-M, Linton NM, Kinoshita R, Yang Y, Hayashi $\mathrm{K}$ et al. The Extent of Transmission of Novel Coronavirus in Wuhan, China, 2020.J. Clin. Med. 2020;9(2):330.

9. Vaishnavi P, Ramkumar S. COVID-19: Survey on Awareness Level and Psychological Status During the Outbreak. IJCRR. 2020;12(18):85-4.

10. Pedro SA, Ndjomatchoua FT, Jentsch P, Tchuenche JM, Anand M, Bauch CT. Conditions for a Second Wave of COVID-19 Due to Interactions Between Disease Dynamics and Social Processes. Front. Phys. 2020;8. 8:574514.

11. Peretti-Watel P, Alleaume C, Léger D. Anxiety, depression and sleep problems: a second wave of COVID-19. General Psychiatry. 2020; 33: e100299.

12. Robertson E, Hershenfield K, Grace SL, Stewart DE. The Psychosocial Effects of Being Quarantined following Exposure to SARS: A Qualitative Study of Toronto Health Care Workers. Can J Psychiatry. 2004;49(6):403-7.

13. Sim K, Huak Chan Y, Chong PN, Chua HC, Wen Soon S. Psychosocial and coping responses within the community health care setting towards a national outbreak of an infectious disease. J. Psychosom. Res. 2010;68(2):195-02.

14. Sønderskov KM, Dinesen PT, Vistisen HT, Østergaard SD. Variation in psychological well-being and symptoms of anxiety and depression during the COVID-19 pandemic: results from a threewave panel survey. Acta Neuropsychiatrica. 2021;33(3):156-9.

15. Thompson RN. Novel Coronavirus Outbreak in Wuhan, China, 2020: Intense Surveillance Is Vital for Preventing Sustained Transmission in New Locations. J. Clin. Med. 2020;9(2):498.

16. Vaishnavi P. Employee Engagement of Private Hospital Nurses: A Comprehensive Study on Their Influencing Factors with Reference to Coimbatore City, March 2020, IJREAM, Volume: 9, Issue: 3 .

Table 1: Awareness, Attitude and Behaviour of People towards Vaccination

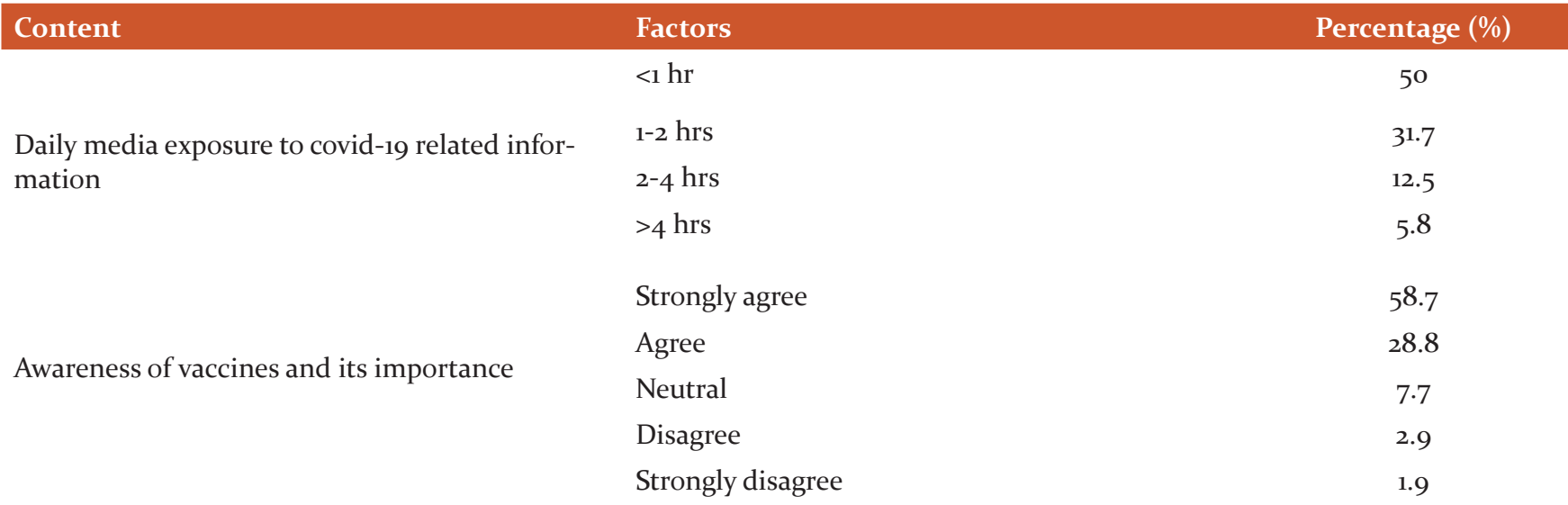


Table 1: (Continued)

\begin{tabular}{|c|c|c|}
\hline Content & Factors & Percentage (\%) \\
\hline \multirow{6}{*}{ Source of awareness about the vaccines } & TV & 19.2 \\
\hline & Social media & $45 \cdot 5$ \\
\hline & Government ads & 15.2 \\
\hline & Newspaper & 10.1 \\
\hline & Friends and family & 10.1 \\
\hline & Others & o \\
\hline \multirow[t]{3}{*}{ Possess vaccine hesitancy } & Yes & 45.2 \\
\hline & No & 54.8 \\
\hline & Very important & 60.6 \\
\hline \multirow{3}{*}{ Think vaccinating is important } & Important & 27.9 \\
\hline & Not much important & 11.5 \\
\hline & Less important & o \\
\hline \multirow[t]{2}{*}{ vaccinated } & Yes & 20.2 \\
\hline & No & 79.8 \\
\hline \multirow{5}{*}{$\begin{array}{l}\text { Safety measures and medicines prescribed by } \\
\text { hospitals after vaccination }\end{array}$} & Yes & 21.4 \\
\hline & No & 78.6 \\
\hline & Feeling safe and relaxed & 49 \\
\hline & Fear of side effects & o \\
\hline & Positive feeling on vaccines & 51 \\
\hline Feeling after vaccination & Others & o \\
\hline Doubt on vaccine safety and its efficacy & Yes & 44.2 \\
\hline \multirow{6}{*}{ Barriers you faced in vaccinating } & No & 55.8 \\
\hline & Travelling long to vaccinate & 7.8 \\
\hline & Maximum time of spending in vaccine centre & 22.3 \\
\hline & Demand of vaccines & 59.9 \\
\hline & Cost of vaccines in private hospitals & 7.8 \\
\hline & Others & 2.2 \\
\hline
\end{tabular}

Table 2: Reason for vaccine hesitancy

\begin{tabular}{lll} 
Reason for Vaccine hesitancy & Mean & Rank \\
Fear of risk or other serious problems & 2.60 & 2 \\
Fear of vaccine or injection & 2.50 & 3 \\
Fear of side effects & 2.50 & 3 \\
Fear of going in crowd to vaccinate & 3.00 & 1 \\
\hline
\end{tabular}

Table 3: Psychological Status of People during Infected and Covid-19 Recovered

$\begin{array}{lcc}\text { Content } & \text { Factors } & \text { Percentage (\%) } \\ \text { Currently tested positive } & \text { Yes } & 8.7 \\ & \text { No } & 91.3 \\ \text { Anyone from family or friends tested } & \text { Yes } & 34.6 \\ \text { positive } & \text { No } & 65.4 \\ \text { Any of you been in ICU for treatment } & \text { Yes } & 9.6\end{array}$


Table 3: (Continued)

\begin{tabular}{lcc} 
Content & Factors & Percentage (\%) \\
Sleep problems affected post recovery & Yes & 45.2 \\
Fear or anxiety during treatment & No & 54.8 \\
& Yes & 71.2 \\
Fear on family safety & No & 29.8 \\
& Yes & 94.2 \\
Felt lonely and depressed during treat- & No & 5.8 \\
ment & Yes & 66.7 \\
Fear much of second wave than first & No & $33 \cdot 3$ \\
& Highly agree & 66.3 \\
& Agree & 24 \\
& Somewhat & $7 \cdot 7$ \\
Experience change in sleeping and eat- & Disagree & 1 \\
ing pattern in second wave & Strongly disagree & 1 \\
Need of psychological support during & Yes & 50 \\
lockdown of second wave & No & 50 \\
& Yes & 57 \\
Need of psychological support after & No & 21 \\
recovering & Somewhat & 22 \\
& Yes & 46 \\
\hline
\end{tabular}

Table 4: Psychological Status of People in Second Wave OF COVID-19

$\begin{array}{llc}\text { Content } & \text { Factors } & \text { Percentage (\%) } \\ & \text { Fear of increase in death } & 45.2 \\ \text { Kind of fear/anxiety during Second wave } & \text { Fear of hospital capacity } & 29.8 \\ & \text { Fear of traveling } & 4.8 \\ & \text { Fear on effectiveness of vaccine } & 8.7 \\ & \text { Fear of unemployment } & 11.5 \\ & \text { Other } & 0 \\ \text { Feel adaptable in second wave lock down than } & \text { Yes } & 53.5 \\ \text { first } & \text { No } & 21.5 \\ & \text { Somewhat } & 25 \\ \text { Mood swings or change in behavior after return } & \text { Yes } & 66.3 \\ \text { from treatment } & \text { No } & 33.7 \\ \text { Impact on your life if the situation continues } & \text { Feeling isolated from friends } & 24 \\ & \text { A negative effect on mental health } & 28.8 \\ & \text { Not having access to creativity } & 1.9\end{array}$


Table 4: (Continued)

\begin{tabular}{|c|c|c|}
\hline Content & Factors & Percentage (\%) \\
\hline \multirow[t]{5}{*}{ Anxiety about health more that first wave } & Strongly agree & 52.9 \\
\hline & Agree & $39 \cdot 4$ \\
\hline & Neutral & $7 \cdot 7$ \\
\hline & Disagree & o \\
\hline & Strongly disagree & o \\
\hline \multirow[t]{2}{*}{ Sleep problems in second wave } & Yes & 39.4 \\
\hline & No & 60.6 \\
\hline \multirow[t]{3}{*}{ Nervous about current circumstances } & Yes & 63.5 \\
\hline & No & 15.4 \\
\hline & Somewhat & 21.1 \\
\hline \multirow[t]{3}{*}{ Feel Stress of second wave } & Yes & 70.2 \\
\hline & No & 11.5 \\
\hline & Somewhat & 18.3 \\
\hline \multirow[t]{5}{*}{ Fear much of second wave than first } & strongly agree & 66.3 \\
\hline & Agree & 24 \\
\hline & Somewhat & $7 \cdot 7$ \\
\hline & Disagree & 1 \\
\hline & Strongly disagree & 1 \\
\hline \multirow{3}{*}{$\begin{array}{l}\text { Need of psychological support during lock- } \\
\text { down of second wave }\end{array}$} & Yes & 57 \\
\hline & No & 21 \\
\hline & Somewhat & 22 \\
\hline \multirow[t]{3}{*}{ Need of psychological support after recovering } & Yes & 46 \\
\hline & No & 28.8 \\
\hline & Somewhat & 25.2 \\
\hline
\end{tabular}

Table 5: Functioning of people during second wave

Functionduringsecond wave

I stay at home and I do not go outside at all

I stay at home and go out occasionally

I stay at home, but I go to work regularly
Mean

\section{Rank}

$\begin{array}{ll}2.47 & 1 \\ 2.75 & 3 \\ 2.50 & 2\end{array}$

\section{Barriers for vaccination}

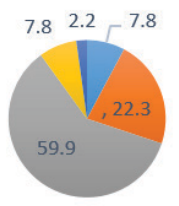

- Travelling long to vaccinate

Maximum time of spending in vaccine centre

nemand of vaccines

u Cost of vaccines in private hospitals

- Others

Figure 1: Barriers for vaccination. 


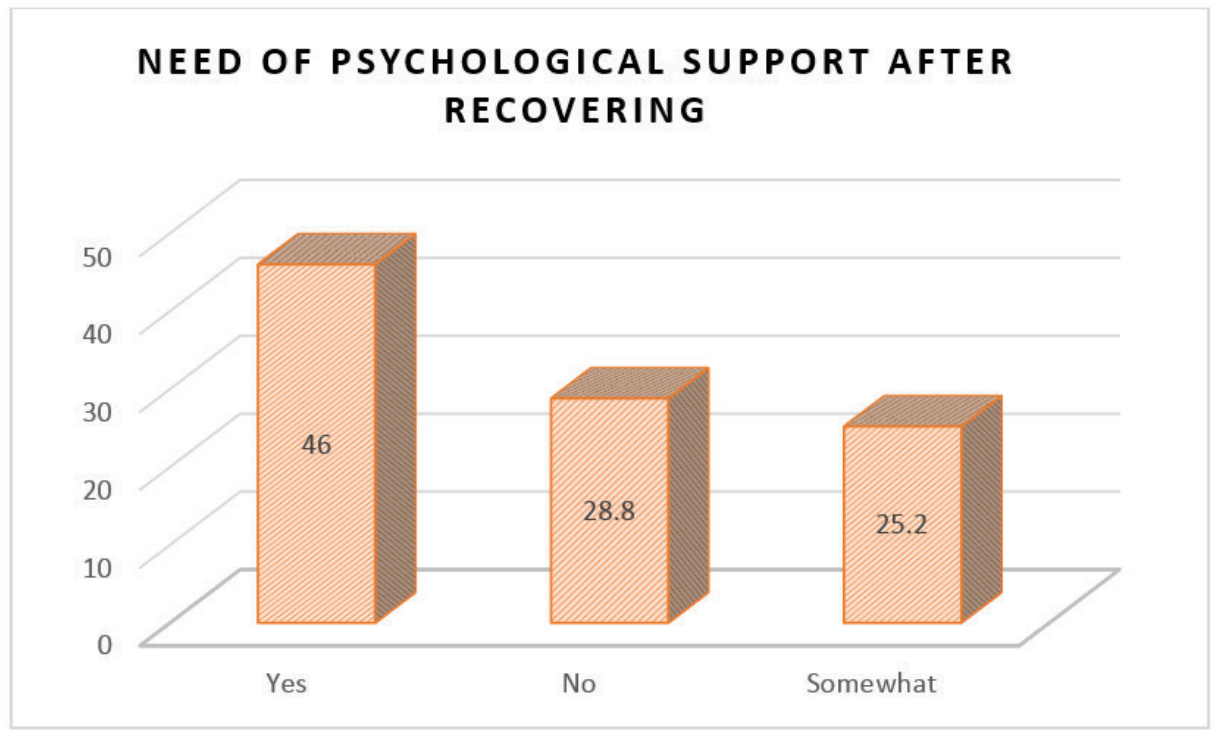

Figure 2: Psychological support need after recovery.

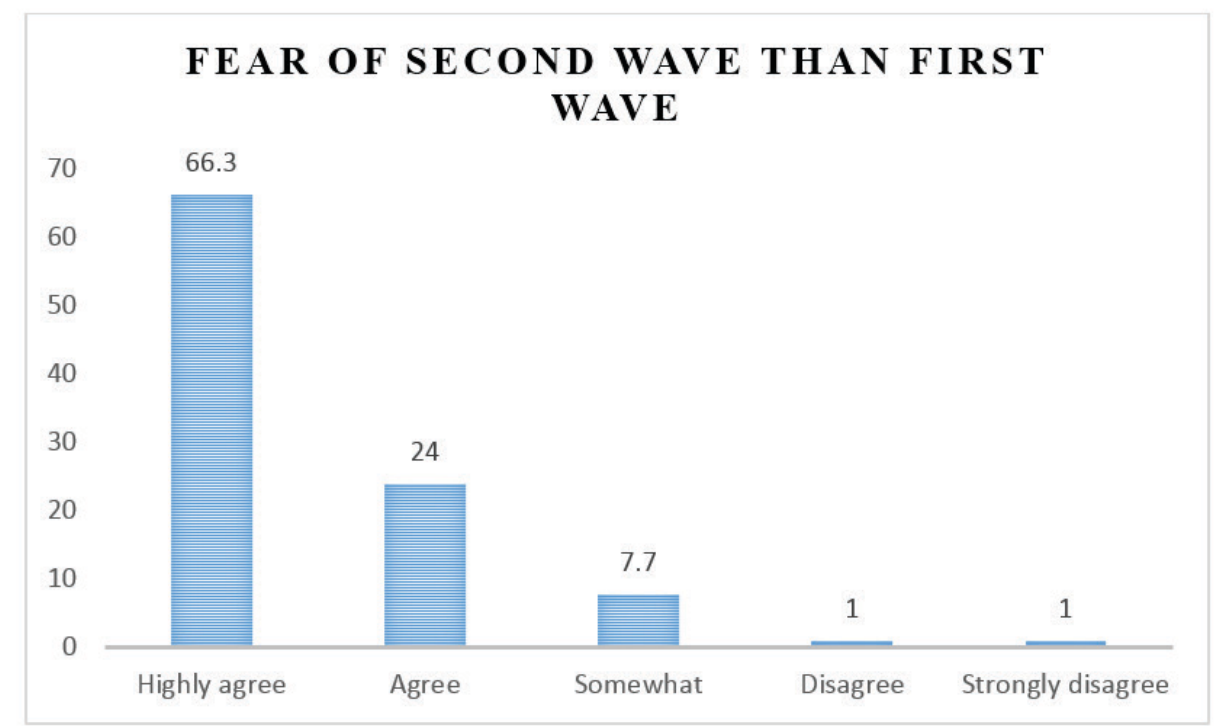

Figure 3: Fear of second wave than first wave. 